\title{
The remineralization potential of cocoa bean extract (Theobroma cacao) to increase the enamel microhardness
}

\author{
Sulistianingsih*, Irmaleny**, Opik Taofik Hidayat** \\ *Department of Police Medicine Indonesian National Police, Indonesia \\ ${ }^{* *}$ Department of Conservative Dentistry Faculty of Dentistry Universitas Padjadjaran, Indonesia
}

\begin{abstract}
Introduction: Remineralization is the process of returning mineral ions into a hydroxyapatite structure characterized by mineral deposition on the enamel surface. The presence of mineral deposition would affect the microhardness of tooth enamel. Fluorine, as the remineralization agent is known with side effects such as fluorosis. Cocoa bean extract contains theobromine that can be used as an alternative remineralization ingredients. The objectives were to determine enamel microhardness after remineralization using cocoa bean extract as natural material and to compare with fluorine as synthetic material. Methods: Thirty-six maxillary first premolar tooth crowns was cut and planted in the epoxy resin. Teeth were then immersed in demineralization solution at pH 4 for 6 hours. The sample were divided into 2 groups, 18 for the fluorine group and the remaining group of cocoa extract. Vickers microhardness test was used before treatment, both after demineralized and remineralized. Results: The value of enamel microhardness before treatment in the fluorine group was $376.17 \mathrm{VHN}$ as average value and the cocoa extract group was $357.33 \mathrm{VHN}$. After demineralization in fluorine group was 268.13 $\mathrm{VHN}$ and cocoa extract group was $235.93 \mathrm{VHN}$. After remineralization in fluorine group and cocoa extract group, respectively, 321.08 VHN and 293.86 VHN. The results of the analysis revealed that the level of enamel microhardness after remineralization was not significantly different in both groups $(p>0.05)$. Conclusions: The findings indicated the ability of cocoa extract to increase the microhardness of enamel and implies the potential as a fluorine substitution for remineralization.
\end{abstract}

Keywords: Enamel microhardness, cocoa extract, remineralization.

P-ISSN 1979-0201, e-ISSN 2549-6212 Available from:http://jurnal.unpad.ac.id/pjd/index

DOI:http://dx.doi.org/10.24198/pjd.vol29no1.13614

Submission: Jan 2017 Publishing: July 2017

\section{INTRODUCTION}

Caries is a chronic process of tooth decay, characterized by the dissolution of minerals from the tooth enamel (demineralization), inorganic and organic substances as a result of an imbalance destruction demineralization to remineralization process. ${ }^{1}$ Demineralization of the tooth is due to decrease of $\mathrm{pH}$ that reachs below the critical $\mathrm{pH}$ (5.5) by lactic acid as a result of bacterial 
metabolism of Streptococcus mutans and Lactobacilli. ${ }^{2.3}$ Exposure to lactic acid in the tooth causes the withdrawal of mineral ions from enamel so that the size of the hydroxyapatite crystals of enamel becomes smaller and causes surface damage to the enamel. This demineralization can reduce enamel hardness. ${ }^{1,4}$

One way to increase the hardness and repair damaged of tooth enamel demineralization is to restore the damaged structure with remineralization process. Fluor is used as the material of hydroxyapatite on the remineralization, and it will change the enamel becomes more stable fluorapatite. In addition, administration of fluorine also can inhibit the metabolism of Streptococcus mutans. ${ }^{5}$

The use of fluor could provide side effects, such as the incidence of dental fluorosis and poisoning, so it should be given with careful technique and proper dosage. ${ }^{6.7}$

Currently modern approach in medicine are turning to utilizing the ingredients derived from nature. Thus the development of plants that have medicinal properties become important and need to be developed because it is believed that drugs derived from natural materials are relatively safe and inexpensive.

Cocoa or Theobroma cacao as natural sources can be utilized in dentistry, with the cocoa extract that contained theobromine, which is expected to be an alternative to fluoride. Some research on Theobromine (3.7-dimethylxantine) contained in the cocoa fruit extracts, found that theobromine can be used as a natural ingredient to prevent dental caries. ${ }^{8}$

Sadeghpour's study on animals, reveals that Theobromine was more effective in preventing caries compare to fluorine. Application of theobromine to the enamel surface will increase the size of hydroxyapatite crystals that will improve enamel resistance to acids so as to prevent demineralization. ${ }^{5,7,8}$ The tooth enamel surface hardness can be affected by the exchange of minerals on the surface of the enamel. Kargul ${ }^{14}$ found that Theobromine $200 \mathrm{mg} / \mathrm{L}$ which is applied to the surface of tooth enamel remineralization effect in the process to increase hardness of tooth enamel. ${ }^{5.8}$

Based on the above background, it should be examined how the effects of cocoa extract in increasing the hardness of tooth enamel in vitro so that it can be used as a substitute for fluorine remineralization.

\section{METHODS}

This study is an in-vitro experimental with 36 teeth samples taken by random sampling, were divided into 2 groups. Group 1 consisted of 18 samples given cocoa extract and Group 2 consisted of 18 samples were given fluorine. The research was conducted at Conservation Clinic of the Faculty of Dentistry Universitas Padjadjaran and Laboratory of Biochemistry and Metallurgy Institute Technology of Bandung.

Research samples were divided into 3 phases, the sample preparation, the research procedures, and data analysis. Thirty-six of the maxillary first premolar tooth was 5 minutes soaked in a solution of $5.12 \% \mathrm{NAOCl}$, then the soft tissue and calculus was cleaned out. Teeth were immersed in a solution of $\mathrm{NaCl} 0.9 \%$ to be given next procedure. Dental crowns are separated from the root by cutting up to $2 \mathrm{~mm}$ below the cementoenamel junction using a low speed of carborundum disc. The buccal crown is placed face down on a plastic mold of mica box shape measuring $1.5 \times 1.5 \times 1.5$ $\mathrm{cm}$. The liquid epoxy resin is stirred and poured into the mold containing the tooth sample. After hardening, the mold is released from the resin. Honed and polished enamel surface with silicone carbide grit paper 400,600 , and 100 , in order to obtain 36 samples of enamel surface is quite wide, flat, and smooth.

Microhardness measurement was conducted on initial enamel at each sample by using a Vickers microhardness tester. Furthermore, all samples was demineralized for 6 hours $(\mathrm{pH} 4)$ in an incubator at $37^{\circ} \mathrm{C}$, then remeasured of its enamel microhardness. Next step was the remineralization, the samples were divided into 2 groups: Group 1, 18 teeth remineralized every day (7 days) for 15 minutes using a solution of 1000 ppm fluoride, then immersed in artificial saliva with $\mathrm{pH} 7$ and stored in an incubator at $37^{\circ} \mathrm{C}$. Group 2 with 18 teeth was demineralized every day (7 days) for 15 minutes using a cocoa extract solution (solution Theobromine $1000 \mathrm{mg} / \mathrm{l}$, then immersed in artificial saliva with $\mathrm{pH} 7$ and stored in an incubator at $37^{\circ} \mathrm{C}$. The enamel microhardness 
test was conducted and the data analysis using statistical paired student $\mathrm{t}$ distributed.

\section{RESULTS}

Enamel hardness testing with Vickers hardness tester performed on buccal enamel surface portion of each samples. The average value of hardness was measured at three test points and analyzed by t-student to compare the difference before and after demineralization and remineralization post cocoa extract and fluorine application. The value of enamel hardness is shown in Table 1.

At Table 1 shown the value of enamel microhardness to the group of fluorine, before the demineralization obtained the highest value 477.0 VHN, with the lowest value on 223.6 VHN. After demineralization was obtained the highest email fluorescent group grade was $361.1 \mathrm{VHN}$, the lowest was 199.8 VHN. After remineralization, the value of enamel hardness of the highest fluorine group was 396.8 VHN, the lowest was 250.8 VHN. The value of enamel microhardness in the cocoa extract group, before demineralization obtained the highest score was $472.8 \mathrm{VHN}$, and the lowest is $184.5 \mathrm{VHN}$. After demineralization obtained an enamel microhardness value at highest cocoa extract group was revealed $326.3 \mathrm{VHN}$, and 100.4 $\mathrm{VHN}$ as the lowest. After remineralization, the enamel microhardness values obtained highest cocoa extract group, 388.7 VHN, and 189.4 VHN was the lowest.

Analysis of changes in the value of enamel hardness in fluorine groups shown in Table 2. It was shown that enamel microhardness fluorine group was decreased after demineralization (from 376.17 into $268.13 \mathrm{VHN}$ ) and increased after remineralization (from 268.13 into $321.08 \mathrm{VHN}$ ).

The analysis result of the average value differences of enamel microhardness in fluorine groups shown in Table 3. It was shown a decline of enamel microhardness in fluorine group. The data reveal as high-significance value ( $\mathrm{p}$ value $<0.01$ ) before and after demineralization, with a fall of 108.03. Meanwhile, after demineralization to remineralization after an increase in microhardness email highly significant $(p<0.01)$ With an increase of 52.95 .

Analysis of changes in the value of enamel microhardness of each group shown in Table 4. Based on Table 4 is known that microhardness email of cocoa group extract decreased after

Table 1. Average rating microhardness of enamel before demineralization, after demineralization, after remineralization with fluor and cocoa extract

\begin{tabular}{ccccccc}
\hline & \multicolumn{3}{c}{ Fluor group } & & & Cocoa extract group \\
\hline No & $\begin{array}{c}\text { Before } \\
\text { demineralization }\end{array}$ & $\begin{array}{c}\text { After } \\
\text { demineralization }\end{array}$ & $\begin{array}{c}\text { After } \\
\text { remineralization }\end{array}$ & $\begin{array}{c}\text { Before } \\
\text { demineralization }\end{array}$ & $\begin{array}{c}\text { After } \\
\text { demineralization }\end{array}$ & $\begin{array}{c}\text { After } \\
\text { remineralization }\end{array}$ \\
\hline 1 & 433.4 & 262.1 & 295.8 & 371.0 & 275.1 & 298.5 \\
2 & 258.2 & 289.3 & 306.5 & 387.3 & 245.7 & 267.6 \\
3 & 417.1 & 266.3 & 321.8 & 401.4 & 211.1 & 325.8 \\
4 & 477.0 & 276.1 & 330.5 & 327.8 & 250.4 & 316.5 \\
5 & 396.4 & 247.0 & 314.3 & 355.2 & 229.2 & 300.1 \\
6 & 316.4 & 313.3 & 285.7 & 274.0 & 271.5 & 250.4 \\
7 & 319.4 & 250.4 & 303.6 & 316.4 & 313.3 & 285.7 \\
8 & 408.5 & 245.2 & 367.2 & 267.4 & 191.0 & 243.0 \\
9 & 428.2 & 273.2 & 345.0 & 472.8 & 100.4 & 288.2 \\
10 & 335.8 & 262.8 & 323.4 & 429.4 & 247.8 & 304.6 \\
11 & 385.0 & 264.4 & 328.8 & 384.1 & 326.3 & 257.1 \\
12 & 406.8 & 286.9 & 396.8 & 358.0 & 303.4 & 388.7 \\
13 & 375.0 & 299.9 & 315.8 & 384.3 & 152.2 & 355.5 \\
14 & 316.9 & 291.5 & 362.7 & 444.0 & 223.9 & 308.4 \\
15 & 436.2 & 206.7 & 251.0 & 184.5 & 185.1 & 189.4 \\
16 & 469.5 & 361.1 & 373.5 & 358.0 & 205.7 & 298.5 \\
17 & 367.6 & 199.8 & 306.3 & 402.4 & 302.3 & 328.0 \\
18 & 223.6 & 230.4 & 250.8 & 314.0 & 212.3 & 283.5 \\
& & & & & \\
\end{tabular}


Table 2. Descriptive analysis of enamel microhardness fluor groups

\begin{tabular}{cc}
\hline Fluor & Mean (SD) \\
\hline Before demineralization & $376.17(69.37)$ \\
After demineralization & $268.13(37.86)$ \\
After remineralization & $321.08(38.82)$ \\
\hline
\end{tabular}

Table 3. Test results difference of enamel microhardness fluor group

\begin{tabular}{cccc}
\hline Test group & $\begin{array}{c}\text { Average } \\
\text { difference }\end{array}$ & p-value & $\begin{array}{c}\text { Conclu- } \\
\text { sion }\end{array}$ \\
\hline $\begin{array}{c}\text { Before vs after } \\
\text { demineralization }\end{array}$ & 108.03 & 0.000 & $\begin{array}{c}\text { Very } \\
\text { significant }\end{array}$ \\
$\begin{array}{c}\text { After demineralization } \\
\text { vs after } \\
\text { remineralization }\end{array}$ & -52.95 & 0.000 & $\begin{array}{c}\text { Very } \\
\text { significant }\end{array}$ \\
\hline
\end{tabular}

Table 4. Descriptive analysis microhardness cocoa extract email group

\begin{tabular}{ll}
\hline Theobromine & Mean (SD) \\
\hline Before demineralization & $357.33(69.40)$ \\
After demineralizationn & $235.93(58.72)$ \\
After remineralization & $293.86(44.41)$ \\
\hline
\end{tabular}

Table 5. Microhardness test result differences cocoa extract email group

\begin{tabular}{cccc}
\hline Test group & $\begin{array}{c}\text { Average } \\
\text { difference }\end{array}$ & p-value & Conclusion \\
\hline $\begin{array}{c}\text { Before vs after } \\
\text { demineralization }\end{array}$ & 121.41 & 0.000 & $\begin{array}{c}\text { Very } \\
\text { significant }\end{array}$ \\
$\begin{array}{c}\text { After demineralization } \\
\text { vs after remineralization }\end{array}$ & -57.93 & 0.000 & $\begin{array}{c}\text { Very } \\
\text { significant }\end{array}$ \\
\hline
\end{tabular}

demineralization (from 357.33 VHN into 235.93 VHN) and increased after remineralization (from 235.93 VHN into 293.86 VHN).

The analysis of the differences of the average value of enamel microhardness of cocoa extract group was shown in Table 5. It was notes that a decline in enamel microhardness group of cocoa extract highly significant $(p<0.01)$ than before demineralization until after demineralization, with a fall of 121.41. Meanwhile, after demineralization to remineralization after an increase in enamel microhardness very significant $(p<0.01)$ with increase of 57.93 . Analysis of the different levels of microhardness fluorine group email and cocoa extract contained in Table 6.

In Table 6 shows that the level of microhardness email prior to demineralization in both groups did not differ significantly $(p$ value $=0.421>0.05$ ) with the difference between the average of 18.83. After the demineralization process, there is an increasing difference in enamel microhardness level in both groups, but the difference was not significant ( $p$ value $=0.059>0.05$ ). After the procedure remineralization obtained emails microhardness level was not significantly different between the two groups ( $p$ value $=0.058>0.05$ )

\section{DISCUSSION}

Demineralization occurs through the diffusion process that is the transfer of molecules or dissolved ions from the enamel to the saliva due to low salivary $\mathrm{pH}$. The enamel structure composed of crystalline hydroxyapatite $\mathrm{Ca}_{10}\left(\mathrm{PO}_{4}\right)_{6}(\mathrm{OH})_{2}$ will cause hydroxyl groups on hydroxyapatite crystals will easily solute in the acid environment (below the critical $\mathrm{pH}$ 4.5). This was because the acid can increase the concentration of hydrogen ions, which would damage the tooth enamel hydroxyapatite crystals. ${ }^{9}$

Demineralization in this study conducted by immersing the samples for 6 hours in artificial saliva with pH 4 (added lactic acid) in an incubator at $37^{\circ} \mathrm{C}$. Demineralization procedure performed for 6 hours intended to produce an initial surface lession of the enamel surface tooth. $4,10,11$

The result of enamel hardness measurement after demineralization was decreased hardness in both groups, fluorine group was $28 \%$ and cocoa extract group was $33.97 \%$. The difference on the degree of hardness decreased is influenced by the composition of the mineral contained on tooth enamel. ${ }^{12}$

Remineralization aims to return mineral ions into the hydroxyapatite structure lost due to the demineralization process. The process of remineralization can occur at high salivary $\mathrm{pH}$, the presence of high calcium and phosphate ions in the saliva, and the availability of adequate organic and inorganic matrices to form crystals. ${ }^{12}$ The process of remineralization naturally occurs 
with the presence of fluoride ions in the saliva, but the fluoride content in saliva is limited. Some experts suggest topical administration fluorine or systemically to enhance the remineralization process and improve resistance to acids email. However, the application of this fluorine cause side effects such as dental fluorosis, and nausea if ingested. ${ }^{4.7}$

Currently, the exploration for fluoride replacement materials for safer remineralization is still being developed. One of the natural ingredients that can be used as remineralization material comes from cocoa beans (chocolate). Nakamoto et al. ${ }^{15}$ found that theobromine contained in cocoa bean can strengthen tooth enamel. ${ }^{13-15}$ Sadeghpour ${ }^{16}$ found that theobromine increased enamel hardness in mice, so it is more resistant to acid. Research on human teeth also gets concluded that theobromine could improve enamel hardness. ${ }^{14.17}$

Based on this study, it appears there was an increase in value of enamel hardness after the remineralization process, the fluorine group was $53 \mathrm{VHN}$ and in group of cocoa extract was 57.93 VHN. In accordance with Sadeghpour ${ }^{16}$ study that theobromine in the cocoa extract is more effective in preventing caries than fluorine, by increasing the size of hydroxyapatite crystals. Kargul ${ }^{14}$ found that Theobromine $200 \mathrm{mg} / \mathrm{L}$ effect on the remineralization process so as to increase the hardness of tooth enamel..$^{5,7,8}$

The effect of fluorine on hydroxyapatite is to replace hydroxy group $(\mathrm{OH})$ which dissolves into hydroxyapatite fluorine. The higher the fluorine concentration, the more stable the fluorapatite will be formed. ${ }^{18.19}$ Theobromine contained in the cocoa extract will increase the hardness of tooth enamel through interstitial reaction as a substitution for the loss of hydroxyl apatite crystals. Theobromine crystals are smaller than hydroxyapatite crystals will make it easier to get into the tunnel and replace ions in the composition of the apatite. The ion replacement will alter the physical properties of apatite..$^{7,14}$

Enamel microhardness after remineralization in the group of fluorine and cocoa extract was increased, but not significantly different for the two groups of fluorine with cocoa extract group $p$ value $0.058>0.05$. Thus the enamel microhardness level after remineralization using cocoa extract, considered as similar results as fluorine.

\section{CONCLUSION}

The enamel surface hardness experienced an increased demineralization after the application of the cocoa extract because it can increase the size of hydroxyapatite crystals. The rate of enamel hardness produced by cocoa extract did not differ significantly with the fluorine solution so it can be used as a remineralization material.

\section{REFERENCES}

1. Kidd EAM. Essential of dental caries. $3^{\text {rd }}$ ed. Oxford: University Press.; 2005.

2. Featherstone JD. Dental caries: A dynamic disease process. Aust Dent J 2008;53:286-91.

3. Fajerskov O, Kidd EAM, Nyvad B. Dental caries, the disease and it's clinical management. $3^{\text {rd }}$ ed. Oxford: Blackwell Munksgaard; 2003. p. 101-10.

4. Hume WR, Mount GJ. Dental caries: the major cause of tooth damage. Preservation and restoration of tooth structure. $2^{\text {nd }} \mathrm{ed}$. Brisbane, Aust: Knowledge Books and Software; 2005. p. 21-34.

5. Kidd EAM, Sumawinata, Faruk T. Dasar-dasar karies: penyakit dan penanggulangannya. Jakarta: Penerbit Buku Kedokteran EGC; 1992. p. 111-2.

6. Srisakthi S. Tooth friendly chocolate. J Pharm Sci Res 2015:7(1):21-34.

7. Nasution Al. Zawil C. The comparison of enamel hardness between fluoride and thoebromine application. Int J Contemp Den Med Rev 2014.

8. Syafira G. Permatasari R. Wardani N. Theobromine effect on enamel surface microhardness: In vitro. J Dent Indonesia. 2012;19(2):32-6.

9. Prasetyo EA. Keasaman minuman ringan menurunkan kekerasan permukaan gigi. Majalah Kedokteran Gigi (Dent J) 2005; 38(2):60.

10. Stookey GK. Featherstone JD, Rapozo-Hilo M, Schemechorn BR, William RA, Baker R, et al. The featherstone laboratory $\mathrm{pH}$ cycling model: A prospective multisite validation exercise. Am J Dent 2011;24(5):322-8.

11. Buzalaf MAR, Hannas AR, Magalhaes AC, 
Rios D, Honorio M, Delbem ACB. pH-cycling models for in-vitro evaluation of the efficacy of fluoridated dentrifrices for caries control: strengths and limitations. J Appl Oral Scie 2010;18(4):316-34. (cited 2015 Jun 10) Available from: https://www.ncbi.nlm.nih. gov/bmc/articles/PMC5349073

12. Salazar MDG. Gasga JR. Microhardness and chemical composition of human teeth. J Mat Res 2003;6(3):367-73.

13. Hemagaran G, Neelakantan P. Remineralization of tooth structure: the future of dentistry. Int J Pharm Tech Res 2014;6(2):487-93.

14. Kargul B. Ozcan M. Peker S. Nakamoto T, Simmons WB, Falster AU et al. Evaluation of human enamel surfaces treated with theobromine: a pilot study. J Oral Health Prev Dent 2012;10(3):275-82.

15. Nakamoto T. Theobromine increase chrystal size. Available from: http://www.iade.confex.
com/iadr/2002.SanDiego/techprogram/ abstract_12740.htm.

16. Sadeghpour A. Chocolate and dental health. In: Wilson PK, Hurst WJ (eds). Chocolate and health: Chemistry, Nutrition, and therapy. London: Royal Society of Chemistry; 2015. p. 196-210.

17. Amaechi B, Porteus N, Ramalingam K, Mensinkai PK, Vasquez RAC, Sadeghpour A et al. Remineralization of artificial enamel lessions by Theobromine. J Caries Rest 2013;47:399-405.

18. Dogan F, Civelek A, Oktay I. Effect of different fluoride concentrations on remineralization of demineralized enamel: An in vitro $\mathrm{p}$ cycling study. OHDMBSC 2004;III(1):20-6.

19. Roberson MT. Cariology: The lession, etiology, prevention, and control. In: Sturdevant's art and science of operative dentistry. Philadelphia: Elsevier; 2006. p. 67-113. 